\title{
Induksi Tunas dari Eksplan Epikotil Jeruk Kasturi (Citrus microcarpa Bunge.) dengan Penambahan BAP dan Kinetin secara In Vitro
}

\section{In Vitro Shoots Induction from Epicotyl Explant of Kasturi Orange (Citrus microcarpa Bunge.) with Addition of BAP and Kinetin}

\author{
Putri Maisarah ${ }^{1}$, Mayta Novaliza Isda ${ }^{1^{*}}$ \\ IJurusan Biologi, Fakultas Matematika dan Ilmu Pengetahuan Alam, Universitas Riau \\ Kampus Binawidya, Kota Pekanbaru 28293, Propinsi Riau, Indonesia \\ Email:maytaisda@yahoo.com *Penulis Korespondensi
}

\begin{abstract}
Kasturi orange (Citrus microcarpa) is a type of fruit that belongs to the genus Citrus, contains vitamin $\mathrm{C}$, and anti-oxidants are also high. Kasturi oranges have relatively long growth characteristics. Generative development after 5 years old. Therefore, by inducing the need for seedlings in large quantities can be achieved in a short time. This study aims to determine the effect of the use of BAP and Kinetin singly or a combination of both ZPT on bud formation from explant epicotyl of castor orange in vitro on MS media and determine the best concentration of BAP and Kinetin singly or a combination of both ZPT for the formation of shoots from explants in vitro castor orange in vitro on MS media. This study used a Completely Randomized Design (CRD) consisting of 16 (sixteen) levels of treatment (control, $0.5 \mathrm{mg} / \mathrm{l}$ BAP, $1 \mathrm{mg} / \mathrm{l}$ BAP, $1.5 \mathrm{mg} / \mathrm{l}$ BAP, $0.5 \mathrm{mg} / \mathrm{l}$ Kinetin , $1 \mathrm{mg} / \mathrm{l}$ Kinetin, $1.5 \mathrm{mg} / \mathrm{l}$ Kinetin, $0.5 \mathrm{mg} / \mathrm{l}$ BAP + $0.5 \mathrm{mg} / 1$ Kinetin, $0.5 \mathrm{mg} / 1$ BAP + $1 \mathrm{mg} / 1$ Kinetin, $0.5 \mathrm{mg} / 1$ BAP + $1.5 \mathrm{mg} / \mathrm{l}$ Kinetin, 1 mg / 1 BAP + $0.5 \mathrm{mg} / \mathrm{l}$ Kinetin, $1 \mathrm{mg} / \mathrm{l}$ BAP + $1 \mathrm{mg} / \mathrm{l}$ Kinetin, $1 \mathrm{mg} / \mathrm{l}$ BAP + $1.5 \mathrm{mg} / \mathrm{l}$ Kinetin, $1.5 \mathrm{mg} / \mathrm{l}$ BAP + 0.5 mg / 1 Kinetin, $1.5 \mathrm{mg} / \mathrm{l}$ BAP + $1 \mathrm{mg} / \mathrm{l}$ Kinetin, $1.5 \mathrm{mg} / \mathrm{I}$ BAP + $1.5 \mathrm{mg} / \mathrm{l}$ Kinetin) and respectively repeated three times. The results of this study indicate that the administration of BAP and Kinetin treatment alone or in combination is able to provide a response to the epicotyl explants of castor orange in the form of time of emergence of shoots, number of shoots, number of leaves and shoot length. The best concentration that is able to form largest number of shoots is P6 treatment (1.5 mg / I Kinetin) of 1.6 shoots.
\end{abstract}

Keywords: Kasturi Orange, Citrus microcarpa Bunge., Buds, Epicotyl, BAP, Kinetin

\begin{abstract}
Abstrak
Jeruk kasturi (Citrus microcarpa) adalah salah satu jenis buah yang termasuk ke dalam genus Citrus, memiliki kandungan vitamin $\mathrm{C}$, dan anti oksidan juga termasuk tinggi. jeruk kasturi memiliki karakteristik pertumbuhan yang tergolong cukup lama. Perkembangan secara generatif setelah berumur 5 tahun. Oleh karena itu, dengan menginduksi tunas kebutuhan bibit dalam jumlah banyak dapat dicapai dengan waktu singkat. Penelitian ini bertujuan untuk mengetahui pengaruh penggunaan BAP dan Kinetin secara tunggal atau kombinasi kedua ZPT tersebut terhadap pembentukan tunas dari eksplan epikotil jeruk kasturi secara in vitro pada media MS dan menentukan konsentrasi terbaik BAP dan Kinetin secara tunggal atau kombinasi kedua ZPT tersebut untuk pembentukan tunas dari eksplan epikotil jeruk kasturi secara in vitro pada media MS. Penelitian ini menggunakan Rancangan Acak Lengkap (RAL) terdiri dari 16 (enam belas) taraf perlakuan (kontrol, 0,5 mg/l BAP, $1 \mathrm{mg} / \mathrm{l}$ BAP, 1,5 mg/l BAP, 0,5 mg/l Kinetin, $1 \mathrm{mg} / \mathrm{l}$ Kinetin, 1,5 mg/l Kinetin, 0,5 mg/l BAP+ 0,5 mg/l Kinetin, 0,5 mg/l BAP + 1 mg/l Kinetin, 0,5 mg/l BAP + 1,5 mg/l Kinetin, 1 mg/l BAP + 0,5 mg/l Kinetin, 1 mg/l BAP + 1 mg/l Kinetin, 1 mg/l BAP + 1,5 mg/l Kinetin, 1,5 mg/l BAP + 0,5 mg/l Kinetin, 1,5 mg/l BAP + 1 mg/l Kinetin, 1,5 mg/l BAP + 1,5 mg/l Kinetin) dan masing-masing diulang sebanyak 3 (tiga) ulangan. Hasil penelitian ini menunjukkan bahwa pemberian perlakuan BAP dan Kinetin tunggal atau kombinasi mampu memberikan respons pada eksplan epikotil jeruk kasturi berupa waktu muncul tunas, jumlah tunas, jumlah daun dan panjang tunas. Konsentrasi terbaik yang mampu membentuk jumlah tunas paling banyak yaitu perlakuan P6 (1,5 mg/l Kinetin) sebesar 1,6 tunas.
\end{abstract}

Katakunci: Jeruk Kasturi, Citrus microcarpa Bunge., Tunas, Epikotil, BAP, Kinetin 


\section{Pendahuluan}

Jeruk kasturi (Citrus microcarpa) adalah salah satu jenis buah yang termasuk ke dalam genus Citrus, memiliki kandungan vitamin $\mathrm{C}$, dan anti oksidan. Perbedaan jeruk kasturi dengan buah jeruk pada umumnya adalah kulit jeruk kasturi berwarna hijau kekuningan dan mengkilat (Bal, 1997). Secara konvesional, jeruk diperbanyak melalui biji dan stek. Perkembangan secara generatif akan dimulai setelah berumur 5 tahun (Abdullah, 2012).

Teknik in vitro merupakan salah satu cara yang dapat diterapkan karena dapat menghasilkan jumlah bibit yang banyak dalam waktu relatif singkat dengan menggunakan bahan tanaman yang sedikit (Nurwahyuni, 2013). Keberhasilan kultur in vitro dipengaruhi oleh faktor endogen dan eksogen. Zat pengatur tumbuh (ZPT) merupakan faktor eksogen yang berfungsi untuk menstimulasi pertumbuhan eksplan dan pertumbuhan tunas dan akar. ZPT yang sering digunakan dalam induksi tunas adalah dari golongan sitokinin seperti kinetin dan BAP (Zulkarnain, 2009).

Pemilihan jenis eksplan juga menentukan keberhasilan kultur in vitro. Pada penelitian ini eksplan epikotil. Menurut Slamet et al. (2011) epikotil merupakan jaringan meristematik yang terdapat pada meristem apek dan adventif sebagai titik tumbuh tanaman yang mengendalikan pertumbuhan. Beberapa keuntungan perbanyakan melalui kultur epikotil adalah daya regenerasi tinggi, waktu pembentukan tunas lebih singkat, efisien, dan aklimatisai cenderung mudah dilakukan karena sistem pembuluhnya lebih sempurna.

Iswari et al. (2013) menyatakan hasil penelitian jeruk Pummelo dari eksplan epikotil membentuk tunas terbaik pada $\mathrm{MS}+1,0 \mathrm{mg} / \mathrm{l} \mathrm{BAP}+1,0$ $\mathrm{mg} / \mathrm{l}$ Kinetin $+0,5 \mathrm{mg} / \mathrm{l}$ NAA yaitu 15 tunas.

Penelitian ini bertujuan untuk mengetahui pengaruh penggunaan BAP dan Kinetin secara tunggal atau kombinasi kedua ZPT tersebut terhadap pembentukan tunas dari eksplan epikotil jeruk kasturi (Citrus microcarpa) secara in vitro pada media MS dan menentukan konsentrasi terbaik BAP dan Kinetin secara tunggal atau kombinasi kedua ZPT tersebut untuk pembentukan tunas dari eksplan epikotil jeruk kasturi (Citrus microcarpa) secara in vitro pada media MS.

\section{Metode Penelitian}

\section{Waktu dan Tempat Penelitian}

Penelitian ini dilaksanakan pada bulan September - November 2019 di Laboratorium Biologi Terpadu Jurusan Biologi Fakultas Matematika dan Ilmu Pengetahuan Alam, Universitas Riau, Kampus Bina Widya, Simpang Baru Kecamatan Tampan, Pekanbaru.

\section{Alat dan Bahan Penelitian}

Alat-alat yang digunakan antara lain Laminar Air Flow Cabinet (LAFC), Autoklaf, oven, timbangan analitik, hot plate, rak kultur, pH meter, Erlenmeyer, botol kultur,gelas ukur, gelas kimia, pipet tetes, cawan petri, pinset, mata pisau, spatula, scalpel, lampu bunsen, batang pengaduk, botol sprayer, panci enamel dan gunting.

Bahan yang digunakan sebagai eksplan adalah epikotil jeruk kasturi in vitro yang sudah berumur 4 minggu, media MS (Murashige and Skoog), agaragar merek swallow, BAP, Kinetin, gula, akuades, alkohol 70\%, 1N HCL, $1 \mathrm{~N} \mathrm{NaOH}$, kertas saring, tissue gulung, aluminium foil, karet gelas, spiritus, kertas label, plastik, dan masker.

\section{Rancangan Penelitian}

Penelitian ini disusun berdasarkan Rancangan Acak Lengkap (RAL) yang terdiri dari 16 (enam belas) perlakuan. Setiap satuan percobaan terdiri dari 1 (satu) eksplan epikotil jeruk kasturi in vitro dengan posisi eksplan ditegakkan pada media. Media yang digunakan adalah MS (Murashige 
and Skoog). Setiap perlakuan terdiri dari 3 ulangan, sehingga diperoleh 48 unit percobaan yaitu: $\mathrm{P}_{0}$ : medium MS tanpa penambahan $\mathrm{BAP} /$ kinetin, $\mathrm{P}_{1}: 0,5 \mathrm{mg} / \mathrm{l}$ BAP, $\mathrm{P}_{2}: 1 \mathrm{mg} / \mathrm{l}$ BAP, $\mathrm{P}_{3}: 1,5 \mathrm{mg} / \mathrm{l}$ BAP, $\mathrm{P}_{4}: 0,5 \mathrm{mg} / \mathrm{l}$ Kinetin, $\mathrm{P}_{5}: 1 \mathrm{mg} / \mathrm{l}$ Kinetin, $\mathrm{P}_{6}: 1,5 \mathrm{mg} / \mathrm{l}$ Kinetin, $\mathrm{P}_{7}: 0,5$ $\mathrm{mg} / \mathrm{l} \mathrm{BAP}+0,5 \mathrm{mg} / \mathrm{l}$ Kinetin, $\mathrm{P}_{8}: 0,5$ $\mathrm{mg} / \mathrm{l} \mathrm{BAP}+1 \mathrm{mg} / \mathrm{l}$ Kinetin, $\mathrm{P}_{9}: 0,5 \mathrm{mg} / \mathrm{l}$ $\mathrm{BAP}+1,5 \mathrm{mg} / \mathrm{l}$ Kinetin, $\mathrm{P}_{10}: 1 \mathrm{mg} / \mathrm{l}$ $\mathrm{BAP}+0,5 \mathrm{mg} / \mathrm{l}$ Kinetin, $\mathrm{P}_{11}: 1 \mathrm{mg} / \mathrm{l}$ BAP +1 mg/l Kinetin, $P_{12}: 1 \mathrm{mg} / \mathrm{l}$ $\mathrm{BAP}+1,5 \mathrm{mg} / \mathrm{l}$ Kinetin, $\mathrm{P}_{13}: 1,5 \mathrm{mg} / \mathrm{l}$ $\mathrm{BAP}+0,5 \mathrm{mg} / \mathrm{l}$ Kinetin, $\mathrm{P}_{14}: 1,5 \mathrm{mg} / \mathrm{l}$ $\mathrm{BAP}+1 \mathrm{mg} / \mathrm{l} \mathrm{Kinetin,} \mathrm{P}_{15}: 1,5 \mathrm{mg} / \mathrm{l}$ $\mathrm{BAP}+1,5 \mathrm{mg} / \mathrm{l}$ Kinetin

\section{Prosedur Penelitian}

Pelaksanaan penelitian ini diawali dengan sterilisasi alat dan pembuatan media tanam MS dengan penambahan BAP dan Kinetin sesuai dengan perlakuan. Kemudian dilakukan penanaman Eksplan In vitro di dalam botol kultur sesuai perlakuan, eksplan yang sudah ditanam selajutnya dilakukan pemeliharaan botol kultur dengan cara menyemprotkan $70 \%$ alkohol setiap 2 hari sekali dan diinkubasi pada suhu $23-25^{\circ} \mathrm{C}$. Parameter pengamatan terdiri dari waktu muncul tunas, panjang tunas, persentase terbentuknya tunas dan jumlah daun.

Data yang diperoleh dari hasil pengamatan dianalisis secara kuantitatif dengan Analysis Of Variance (ANOVA) berdasarkan uji $\mathrm{F}$ taraf $5 \%$.

\section{Hasil dan Pembahasan}

\section{Persentase Terbentuknya Tunas dari Eksplan Epikotil In Vitro Jeruk Kasturi (Citrus microcarpa Bunge.)}

Pembentukan tunas dilakukan pada eksplan epikotil jeruk kasturi (Citrus microcarpa Bunge.) yang berasal dari tanaman jeruk berumur 4 minggu pada media MS yang ada di laboratorium Biologi terpadu FMIPA Universitas Riau. Eksplan epikotil dipindahkan ke media MS dengan penambahan BAP $(0,5 \mathrm{mg} / \mathrm{L}, 1 \mathrm{mg} / \mathrm{L}$, dan $1,5 \mathrm{mg} / \mathrm{L})$, Kinetin $(0,5 \mathrm{mg} / \mathrm{L}, 1$ $\mathrm{mg} / \mathrm{L}$, dan $1,5 \mathrm{mg} / \mathrm{L}$ ), dan kombinasi BAP dan Kinetin sesuai perlakuan.

Pengamatan persentase terbentuknya tunas dilakukan selama 72 hari. Berdasarkan penelitian ini pemberian konsentrasi BAP dan Kinetin secara tunggal dan kombinasi pada media MS menghasilkan persentase terbentuknya tunas sebesar 60-100\%, Persentase terbentuknya tunas dari perlakuan $\mathrm{P}_{0}$ hingga $\mathrm{P}_{14}$ yaitu $100 \%$, sedangkan pada perlakuan $\mathrm{P}_{15}$ persentase terbentuknya tunas $60 \%$. Pengaruh pemberian BAP dan Kinetin secara tunggal dan kombinasi terhadap persentase terbentuknya tunas ditunjukkan pada Tabel 1.

Pada Tabel 1 terlihat bahwa tanpa pemberian ZPT sudah mampu untuk membentuk tunas. Hal ini disebabkan sitokinin endogen pada tanaman tersebut sudah cukup untuk membentuk tunas. Semakin tinggi konsentrasi dari kombinasi BAP dan Kinetin yang diberikan maka presentase terbentuknya tunas yang dihasilkan semakin rendah. Penurunan presentase pada perlakuan terjadi pada P15 (1,5 $\mathrm{mg} / \mathrm{L} \mathrm{BAP}+1,5 \mathrm{mg} / \mathrm{L}$ Kinetin) dimana presentase pembentukan tunas dihasilkan sebesar 60\%. Terjadinya penurunan presentase pembentukan tunas ini diduga pemberian BAP dan Kinetin pada media MS dalam konsentrasi tinggi dapat menghambat terbentuknya tunas. Hal ini sesuai dengan pernyatan Fitriani (2019) bahwa penurunan jumlah tunas disebabkan konsentrasi sitokinin endogen cukup tinggi sehingga ketika penambahan sitokinin dalam konsentrasi tinggi malah menghambat pembentukan tunas. 
Tabel 1. Presentase Terbentuknya Tunas dari Eksplan Epikotil In Vitro Jeruk kasturi (Citrus microcarpa Bunge.) pada 72 HST.

\begin{tabular}{cccc}
\hline \hline & \multicolumn{2}{c}{ Perlakuan } & $\begin{array}{c}\text { Persentase } \\
\text { Kode }\end{array}$ \\
\cline { 2 - 3 } & $\begin{array}{c}\text { Penambahan } \\
\text { BAP(mg/L) }\end{array}$ & $\begin{array}{c}\text { Penambahan } \\
\text { Kinetin }(\mathbf{m g} / \mathbf{L})\end{array}$ \\
\hline \hline $\mathrm{P}_{0}$ & 0 & 0 & 100 \\
$\mathrm{P}_{1}$ & 0,5 & 0 & 100 \\
$\mathrm{P}_{2}$ & 1 & 0 & 100 \\
$\mathrm{P}_{3}$ & 1,5 & 0 & 100 \\
$\mathrm{P}_{4}$ & 0 & 0,5 & 100 \\
$\mathrm{P}_{5}$ & 0 & 1 & 100 \\
$\mathrm{P}_{6}$ & 0 & 1,5 & 100 \\
$\mathrm{P}_{7}$ & 0,5 & 0,5 & 100 \\
$\mathrm{P}_{8}$ & 0,5 & 1 & 100 \\
$\mathrm{P}_{9}$ & 0,5 & 1,5 & 100 \\
$\mathrm{P}_{10}$ & 1 & 0,5 & 100 \\
$\mathrm{P}_{11}$ & 1 & 1 & 100 \\
$\mathrm{P}_{12}$ & 1 & 1,5 & 100 \\
$\mathrm{P}_{13}$ & 1,5 & 0,5 & 100 \\
$\mathrm{P}_{14}$ & 1,5 & 1 & 100 \\
$\mathrm{P}_{15}$ & 1,5 & 1,5 & 60 \\
\hline \hline
\end{tabular}

Awal munculnya tunas pada eksplan epikotilterdapatnya gumpalan berwarna hijau pada bagian ujung atas eksplan epikotil seperti terlihat pada (Gambar 1.a). Gumpalan ini membentuk tonjolan berwarna hijau. Tonjolan inilah yang disebut dengan nodul menjadi tanda kemunculan tunas pada eksplan epikotil jeruk kasturi (Citrus microcarpa Bunge.), sedangkan pada (Gambar 1.b) terbentuknya tunas.

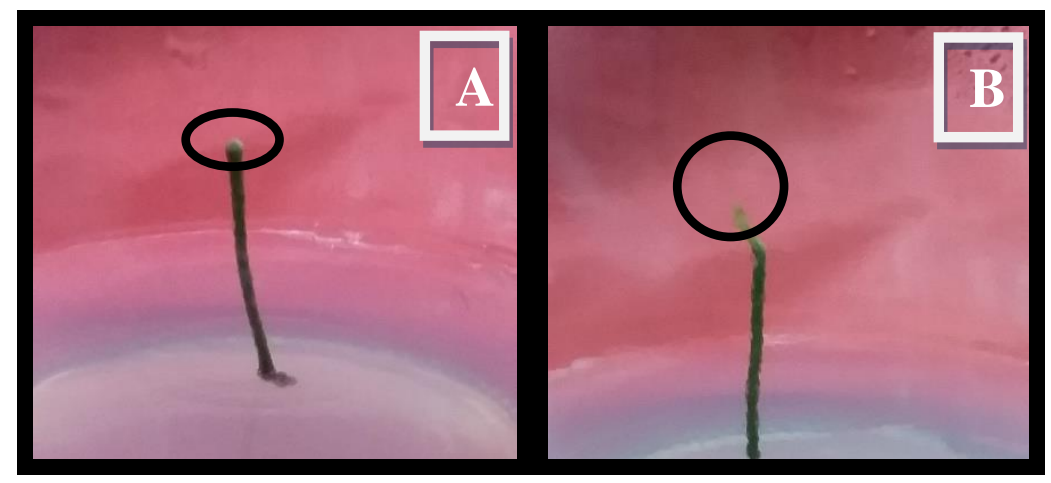

Gambar 1. Pertumbuhan tunas dari eksplan epikotil in vitro jeruk kasturi (Citrus microcarpa Bunge.): A) tonjolan berwarna hijau; B) terbentuknya tunas.

Pada penelitian ini terlihat bahwa terjadinya organogenesis tidak langsung yang diawali dengan pembentukan nodul. Nodul tersebut berbentuk tumpul dan akan menjadi calon tunas' yang memiliki bentuk dan pertumbuhan normal dan berwarna hijau. Hariono et al. (2018) menyatakan bahwa nodul merupakan sel yang berkembang dengan membentuk tonjolan berwarna putih hingga hijau yang tidak meruncing di suatu bagian 
organ yang akan menjadi calon tunas jika kondisi lingkungan dan nutrisi yang didapatkan sesuai. Pada hasil penelitian ini pembentukan tunas terjadi secara organogenesis tidak langsung yang diawali dengan munculnya nodul.
Terbentuknya tunas yang diawali dengan terbentuknya nodul akan menghasilkan tunas lebih banyak sehingga akan menguntungkan dalam perbanyakan tunas secara in vitro.

Tabel 2. Rerata Waktu Muncul Tunas, Jumlah Tunas, Jumlah Daun, dan Panjang Tunas dari Eksplan Epikotil In Vitro Jeruk kasturi (Citrus microcarpa Bunge.) 72 HST

\begin{tabular}{|c|c|c|c|c|c|c|}
\hline \multirow[b]{2}{*}{ Kode } & \multicolumn{2}{|c|}{ Perlakuan } & \multicolumn{4}{|c|}{ Parameter Pengamatan } \\
\hline & BAP & Kinetin & $\begin{array}{c}\text { Waktu } \\
\text { Muncul } \\
\text { Tunas (HST) }\end{array}$ & $\begin{array}{c}\text { Jumlah } \\
\text { Tunas }\end{array}$ & $\begin{array}{l}\text { Jumlah } \\
\text { Daun }\end{array}$ & $\begin{array}{c}\text { Panjang } \\
\text { Tunas }\end{array}$ \\
\hline $\mathrm{P}_{0}$ & 0 & 0 & $31,3 \pm 7,5^{\mathrm{abc}}$ & $1,3 \pm 0,5^{\mathrm{bc}}$ & $2,6 \pm 2,0^{\mathrm{bc}}$ & $0,4 \pm 0,2^{\mathrm{abcd}}$ \\
\hline $\mathrm{P}_{1}$ & 0,5 & 0 & $24,0 \pm 5,1^{\mathrm{a}}$ & $1,0 \pm 0,0^{\mathrm{ab}}$ & $2,3 \pm 0,5^{\mathrm{abc}}$ & $0,2 \pm 0,0^{\mathrm{abc}}$ \\
\hline $\mathrm{P}_{2}$ & 1 & 0 & $32,6 \pm 4,6^{\mathrm{abc}}$ & $1,0 \pm 0,0^{\mathrm{ab}}$ & $1,3 \pm 0,5^{\mathrm{ab}}$ & $0,2 \pm 0,1^{\mathrm{abc}}$ \\
\hline $\mathrm{P}_{3}$ & 1,5 & 0 & $33,6 \pm 5,5^{a b c}$ & $1,0 \pm 0,0^{\mathrm{ab}}$ & $1,0 \pm 0,0^{\mathrm{ab}}$ & $0,1 \pm 0,0^{\mathrm{ab}}$ \\
\hline $\mathrm{P}_{4}$ & 0 & 0,5 & $33,3 \pm 5,7^{a b c}$ & $1,0 \pm 0,0^{\mathrm{ab}}$ & $2,0 \pm 0,0^{\mathrm{abc}}$ & $0,2 \pm 0,1^{\mathrm{abc}}$ \\
\hline $\mathrm{P}_{5}$ & 0 & 1 & $34,6 \pm 5,7^{a b c}$ & $1,0 \pm 0,0^{\mathrm{ab}}$ & $1,6 \pm 1,1^{\mathrm{ab}}$ & $0,4 \pm 0,4^{\mathrm{bcd}}$ \\
\hline $\mathrm{P}_{6}$ & 0 & 1,5 & $27,3 \pm 1,1^{\mathrm{ab}}$ & $1,6 \pm 0,5^{\mathrm{bc}}$ & $3,6 \pm 0,5^{\mathrm{c}}$ & $0,3 \pm 0,1^{\mathrm{abcd}}$ \\
\hline $\mathrm{P}_{7}$ & 0,5 & 0,5 & $46,6 \pm 2,8^{b c}$ & $1,0 \pm 0,0^{\mathrm{ab}}$ & $1,0 \pm 0,0^{\mathrm{ab}}$ & $0,1 \pm 0,0^{\mathrm{ab}}$ \\
\hline $\mathrm{P}_{8}$ & 0,5 & 1 & $50,3 \pm 0,5^{c}$ & $1,0 \pm 0,0^{\mathrm{ab}}$ & $1,0 \pm 0,0^{\mathrm{ab}}$ & $0,1 \pm 0,0^{\mathrm{ab}}$ \\
\hline $\mathrm{P}_{9}$ & 0,5 & 1,5 & $48,3 \pm 2,8^{\mathrm{bc}}$ & $1,0 \pm 0,0^{\mathrm{ab}}$ & $1,0 \pm 0,0^{\mathrm{ab}}$ & $0,1 \pm 0,0^{\mathrm{ab}}$ \\
\hline $\mathrm{P}_{10}$ & 1 & 0,5 & $34,0 \pm 6,9^{a b c}$ & $1,0 \pm 0,0^{\mathrm{ab}}$ & $1,3 \pm 0,5^{\mathrm{ab}}$ & $0,2 \pm 0,0^{\mathrm{abc}}$ \\
\hline $\mathrm{P}_{11}$ & 1 & 1 & $50,0 \pm 0,0^{c}$ & $1,0 \pm 0,0^{\mathrm{ab}}$ & $1,0 \pm 0,0^{\mathrm{ab}}$ & $0,1 \pm 0,0^{\mathrm{ab}}$ \\
\hline $\mathrm{P}_{12}$ & 1 & 1,5 & $40,0 \pm 0,0^{\mathrm{abc}}$ & $1,0 \pm 0,0^{\mathrm{ab}}$ & $1,3 \pm 0,5^{\mathrm{ab}}$ & $0,4 \pm 0,3^{\mathrm{cd}}$ \\
\hline $\mathrm{P}_{13}$ & 1,5 & 0,5 & $29,3 \pm 1,1^{\mathrm{abc}}$ & $1,3 \pm 0,5^{\mathrm{bc}}$ & $2,3 \pm 2,3^{\mathrm{abc}}$ & $0,6 \pm 0,1^{\mathrm{d}}$ \\
\hline $\mathrm{P}_{14}$ & 1,5 & 1 & $26,6 \pm 1,1^{\mathrm{ab}}$ & $1,0 \pm 0,0^{\mathrm{ab}}$ & $1,6 \pm 1,1^{\mathrm{ab}}$ & $0,2 \pm 0,1^{\mathrm{abc}}$ \\
\hline $\mathrm{P}_{15}$ & 1,5 & 1,5 & $47,3 \pm 41,0^{\mathrm{bc}}$ & $0,6 \pm 0,5^{\mathrm{a}}$ & $0,6 \pm 0,5^{\mathrm{a}}$ & $0,06 \pm 0,05^{\mathrm{a}}$ \\
\hline
\end{tabular}

Keterangan: *Angka yang diikuti oleh huruf yang berbeda pada kolom yang sama menunjukan berbeda nyata $(\mathrm{P}>0,05)$ pada uji DMRT taraf $5 \%$.

\section{Waktu Muncul Tunas dari Eksplan Epikotil In Vitro Jeruk Kasturi (Citrus microcarpa Bunge.)}

Berdasarkan Tabel 2 induksi tunas dari eksplan epikotil in vitro jeruk kasturi selama 72 HST dapat diketahui bahwa perlakuan $\mathrm{P}_{1}$ tidak berbeda nyata terhadap perlakuan $\mathrm{P}_{0}, \mathrm{P}_{2}, \mathrm{P}_{3}, \mathrm{P}_{4}, \mathrm{P}_{5}, \mathrm{P}_{6}$, $\mathrm{P}_{10}, \quad \mathrm{P}_{12}, \quad \mathrm{P}_{13}$, dan $\mathrm{P}_{14}$, sedangkan perlakuan $\mathrm{P}_{1}$ berbeda nyata terhadap perlakuan $\mathrm{P}_{7}, \mathrm{P}_{8}, \mathrm{P}_{9}, \mathrm{P}_{11}$, dan $\mathrm{P}_{15}$.

Eksplan epikotil in vitro jeruk kasturi (Citrus microcarpa Bunge.) pada perlakuan $\mathrm{P}_{1}$ dengan konsentrasi 0,5 $\mathrm{mg} / \mathrm{L}$ BAP lebih cepat membentuk tunas dibandingkan perlakuan lainnya. Eksplan pada perlakuan $\mathrm{P}_{1}$ mampu membentuk tunas setelah 24 hari ditanam pada media MS. Eksplan epikotil in vitro mampu membentuk tunas dengan baik dimungkinkan karena eksplan menyerap nutrisi pada media dengan cepat sehingga memicu respon pembentukan tunas. Keberadaan hormon endogen dari eksplan sendiri kemungkinan cukup tinggi sehingga saat ditambahkan hormon eksogen dalam konsentrasi rendah akan mempercepat pembentukan tunas. Rasud et al. (2015) menyatakan bahwa BAP masuk ke dalam jaringan melalui bagian eksplan 
yang dilukai, selanjutnya BAP akan merangsang sel-sel pada jaringan eksplan untuk membelah dan berdiferensiasi membentuk tunas. Penyerapan ZPT tersebut selanjutnya akan menyebabkan peningkatan kandungan ZPT (hormon endogen) dalam tubuh tanaman.

Pada perlakuan kombinasi BAP dan Kinetin menghasilkan waktu muncul tunas yang lambat dengan konsentrasi perlakuan 1,5 mg/l BAP+ $1,5 \mathrm{mg} / \mathrm{l}$ Kinetin pada penelitian ini. Lamanya waktu terbentuk tunas kemungkinan disebabkan dari kombinasi dari kedua sitokinin ini memperlambat kemunculan tunas karena BAP ini bersifat merangsang terbentuknya tunas. Razi (2017) menyatakan bahwa kinetin berfungsi untuk pengatur pembelahan sel dan morfogenesis. Kesesuaian pemakaian zat pengatur tumbuh juga merupakan faktor pembatas bagi spesies tanaman.

\section{Jumlah Tunas dari Eksplan Epikotil In Vitro Jeruk Kasturi (Citrus microcarpa Bunge.)}

Berdasarkan Tabel 2 induksi tunas dari eksplan epikotil in vitro jeruk kasturi selama 72 HST dapat diketahui bahwa perlakuan $\mathrm{P}_{15}$ berbeda nyata dengan perlakuan $\mathrm{P}_{13}, \mathrm{P}_{6}$, dan $\mathrm{P}_{0}$ akan tetapi $\mathrm{P}_{15}$ tidak berbeda nyata terhadap perlakuan $\mathrm{P}_{14}, \mathrm{P}_{12}, \mathrm{P}_{11}, \mathrm{P}_{10}, \mathrm{P}_{9}, \mathrm{P}_{8}, \mathrm{P}_{7}, \mathrm{P}_{5}$, $\mathrm{P}_{4}, \mathrm{P}_{3}, \mathrm{P}_{2}$, dan $\mathrm{P}_{1}$. Jumlah tunas terbanyak pada perlakuan 1,5 Kinetin dengan rerata sebesar 1,6 tunas, hal ini menjukkan bahwa kinetin tunggal dapat memacu pertumbuhan tunas. Hal ini sesuai dengan pendapat Cahyati et al. (2016) yang menyatakan kinetin berpengaruh dalam mempercepat induksi tunas. (Gambar 2).



Gambar 2. Jumlah tunas dari eksplan epikotil in vitro jeruk kasturi (Citrus microcarpa Bunge.): A) Perlakuan 1,5 mg/l Kinetin; B) Perlakuan 1,5 mg/l BAP+ 1,5 mg/l Kinetin.

Pada perlakuan BAP jumlah tunas terbaik terdapat pada ketiga perlakuan sebesar $0,5 \mathrm{mg} / \mathrm{L}, 1 \mathrm{mg} / \mathrm{L}$, dan $1,5 \mathrm{mg} / \mathrm{L}$ BAP. Hal ini menunjukkan bahwa BAP sesuai dengan perannya yang berfungsi untuk pembentukan tunas. Menurut Shinta (2017) BAP bersifat lebih merangsang multiplikasi tunas dibanding kinetin. Sedangkan kinetin mempunyai pengaruh mempercepat induksi tunas. Jumlah tunas terendah terdapat pada perlakuan kombinasi $1,5 \mathrm{mg} / \mathrm{l} \mathrm{BAP}+1,5 \mathrm{mg} / \mathrm{l}$
Kinetin sebesar 0,6 tunas. Hal ini disebabkan perlakuan kombinasi yang ditambahkan dengan konsentrasi tertinggi dapat menghambat pertumbuhan tunas tersebut.

Berbeda dengan Parihar \& Kumar (2015) yang melakukan penelitian induksi tunas dengan menggunakan eksplan epikotil Aegle marmelos pada media MS dengan konsentrasi BAP dan Kinetin yang dikombinasikan menghasilkan jumlah tunas terbaik pada konsentrasi $1,5 \mathrm{mg} / \mathrm{L}$ 
BAP+ 1,5mg/L Kinetin sebesar 19,35 tunas, untuk perlakuan tunggal menghasilkan jumlah tunas sebesar 11,41 tunas pada konsentrasi $1,0 \mathrm{mg} / \mathrm{L}$ BAP, dan perlakuan $1,5 \mathrm{mg} / \mathrm{L}$ Kinetin menghasilkan jumlah tunas sebesar 13,15 tunas.

ZPT jenis sitokinin banyak digunakan untuk merangsang pertumbuhan tunas. Karjadi \& Buchory (2008) menyatakan bahwa Selain untuk pembentukan tunas, sitokinin juga digunakan untuk metabolisme sel. Pada penelitian ini jumlah tunas yang didapat tidak terlalu banyak sehingga eksplan epikotil perlu dilakukan subkultur ke media yang baru agar mendapatkan jumlah tunas yang lebih banyak.

\section{Jumlah Daun dari Eksplan Epikotil In Vitro Jeruk Kasturi (Citrus microcarpa Bunge.)}

Berdasarkan Tabel 2 induksi tunas dari eksplan epikotil in vitro jeruk kasturi selama 72 HST dapat diketahui bahwa perlakuan P6 berbeda nyata dengan perlakuan $\mathrm{P} 2, \mathrm{P} 3, \mathrm{P} 5, \mathrm{P} 7, \mathrm{P} 8$, P9, P10, P11, P12, P14 dan P15, akan tetapi perlakuan P6 tidak berbeda nyata dengan perlakuan $\mathrm{P} 0, \mathrm{P} 1, \mathrm{P} 4$ dan $\mathrm{P} 13$. Rata- rata jumlah daun terbanyak hasil penelitian yang sudah dilakukan pada eksplan epikotil pada konsentrasi 1,5 mg/l Kinetin sebesar 3,6 helai, sedangkan jumlah daun terendah didapat pada konsentrasi $1,5 \mathrm{mg} / \mathrm{l} \mathrm{BAP}$ + 1,5 mg/l Kinetin sebesar 0,6 helai. Rendahnya jumlah daun ini disebabkan karena kombinasi dengan konsentrasi tinggi belum mampu untuk memperbanyak jumlah daun pada tanaman ini.

Widyastuti (2017) menyatakan bahwa pembentukan daun pada kultur in vitro sangat dipengaruhi oleh sitokinin dan auksin baik eksogen maupun endogen. Sedangkan banyaknya jumlah daun disebabkan karena eksplan epikotil mampu membentuk daun terbanyak dengan jumlah daun 5 per eksplan dengan penambahan sitokinin secara eksogen. Fitriani (2019) menyatakan bahwa hormon endogen berperan dalam menghasilkan respon pada eksplan. Hormon yang berbeda pada setiap eksplan akan memberikan respon yang berbeda juga.

\section{Panjang Tunas dari Eksplan Epikotil In Vitro Jeruk Kasturi (Citrus microcarpa Bunge.)}

Berdasarkan Tabel 2 induksi tunas dari eksplan epikotil in vitro jeruk kasturi selama 72 HST dapat diketahui bahwa perlakuan $\mathrm{P}_{13}$ berbeda nyata terhadap perlakuan $\mathrm{P}_{1}, \mathrm{P}_{2}, \mathrm{P}_{3}, \mathrm{P}_{4}, \mathrm{P}_{7}, \mathrm{P}_{8}$, $\mathrm{P}_{9}, \mathrm{P}_{10}, \mathrm{P}_{11}, \mathrm{P}_{14}$ dan $\mathrm{P}_{15}$. Akan tetapi $\mathrm{P}_{13}$ tidak berbeda nyata $\mathrm{P}_{0}, \mathrm{P}_{5}, \mathrm{P}_{6}$, dan $\mathrm{P}_{12}$. Rerata panjang tunas tertinggi terdapat pada perlakuan dengan penambahan 1,5 $\mathrm{mg} / \mathrm{l} \mathrm{BAP}+0,5 \mathrm{mg} / \mathrm{l} \mathrm{Kinetin} \mathrm{sebesar} \mathrm{0,6}$ panjang tunas. Panjang tunas terendah terdapat pada perlakuan dengan penambahan $1,5 \mathrm{mg} / \mathrm{l} \mathrm{BAP}+1,5 \mathrm{mg} / \mathrm{l}$ Kinetin. Tingginya panjang tunas ini disebabkan karena dengan penambahan konsentrasi $1,5 \mathrm{mg} / \mathrm{l} \mathrm{BAP}+0,5 \mathrm{mg} / \mathrm{l}$ Kinetin dapat memicu panjang tunas pada eksplan epikotil jeruk kasturi (Citrus microcarpa Bunge.). Variasi panjang tunas yang didapatkan ini diduga karena jumlah sitokinin endogen pada eksplan berbeda. Andaryani (2010) menyatakan bahwa penambahan sitokinin secara eksogen pada media kultur dapat menginduksi pembelahan sel-sel meristem pada eksplan dan mempengaruhi sel lainnya untuk berkembang menjadi tunas.

Rendahnya panjang tunas diduga karena konsentrasi $1,5 \mathrm{mg} / \mathrm{l} \mathrm{BAP}$ dan $0,5 \mathrm{mg} / \mathrm{l}$ Kinetin sudah mencukupi untuk pembentukan tunas karena di dalam eksplan terdapat jaringan meristematik. Menurut Joni et al. (2014) kandungan nitrogen yang tinggi pada media MS akan menginduksi terbentuknya hormon sitokinin pada eksplan yang akan memicu pembelahan sel sehingga banyak terbentuk tunas, namun elongasi tunas menjadi terhambat. Hasil penelitian Gawad et al. (2012) dimana pemberian kinetin 6,0 $\mathrm{mg} / \mathrm{l}$ hanya menghasilkan $1,62 \mathrm{~cm}$, 
sementara BAP 6,0 mg/l mencapai 4,56 $\mathrm{cm}$. Hal ini sejalan dengan hasil penelitian Ibrahim \& Hartati (2014) bahwa pemberian Kinetin 2,0 mg/l pada pengamatan di bulan ke 3 setelah kultur menghasilkan tinggi tanaman tertinggi $4,34 \mathrm{~cm}$, sementara pemberian BAP 2,0 $\mathrm{mg} / \mathrm{l}$ hanya $3,52 \mathrm{~cm}$.

\section{Kesimpulan}

Pemberian BAP dan Kinetin secara tunggal atau kombinasi keduanya berpengaruh nyata terhadap waktu muncul tunas, jumlah tunas, jumlah daun dan panjang tunas, namun tidak berpengaruh nyata terhadap persentase terbentuknya tunas dari eksplan epikotil jeruk kasturi. Perlakuan $\mathrm{P}_{0}$ hingga $\mathrm{P}_{14}$ menghasilkan terbentuknya tunas tertinggi yaitu $100 \%$. Perlakuan yang menghasilkan jumlah tunas terbanyak terdapat pada perlakuan dengan penmabahan 1,5 mg/l Kinetin yaitu dengan rerata sebesar 1,6 tunas.

\section{Daftar Pustaka}

Abdullah, M.H.R.O.M., Ch'ng. P.E., \& Yunus, N.A. (2012). Some physical properties of musk lime (Citrus microcarpa). International Journal of Agricultural and Biosystems Engineering 6(12): 1122-1125.

Andaryani, S. (2010). Kajian Penggunaan Berbagai Konsentrasi BAP dan 2,4-D Terhadap Induksi Kalus Jarak Pagar (Jatropha curcas L.) secara In Vitro [Skripsi]. Universitas Sebelas Maret Surakarta.

Bal JS, (1997). Fruit Growing. Kalyani Publishers. New Delhi.

Cahyati, S.M.N. Isdadan W., \& Lestari. (2016). Induksi tunas dari eksplan kotiledon dan epikotil in vitro jeruk siam (Citrus nobilis lour.) asal kampar pada media ms. Jurnal Riau Biologia 1 (5): 31-38.

Fitriani, D. (2019). Perbanyakan Tunas Jeruk Kasturi (Citrus microcarpa Bunge.) dari Eksplan Biji dan Kotiledon secara In Vitro dengan penambahan BAP dan Gandasil D [Skripsi]. Universitas Riau.

Gawad, A. E. M. A., Nehad, Mahdy, H.A., \& Boshra, E.S. (2012). In vitro micropropagation protocol and acclimatization of coffee trees (Coffea Arabica L.). J. Plant Production, Mansoura Univ 3 (1): $109-116$.

Hariono, E. M.N., Isda., \& Fatonah, S. (2018). Pembentukan nodul dari biji manggis (Garcinia mangostana L.) asal bengkalis pada media WPM dengan penambahan BAP dan madu. Journal of Biology 11 (1): 16-24.

Ibrahim, M. S. D., R. \& Hartati, R.S. (2014). Multiplikasi tunas kopi arabika menggunakan kinetin dan 6benzylaminopurine. Prosiding Seminar Nasional Agroinovasi Spesifik Lokasi untuk Keutuhan Pangan Pada Era Masyarakat Ekonomi ASEAN (pp. 1114-1123). Bogor, Indonesia.

Joni, Y.Z., Efendi, D. I., \& Roostika. (2014). Morfogenesis eksplan keping biji dari tiga klon manggis (Garcinia mangostana 1.) pada tiga jenis media dasar. Journal Horticulture 24 (2): 94-101.

Karjadi, A.K., \& Buchory. A. (2007). Pengaruh penambahan auksin dan sitokinin terhadap pertumbuhan tunas bawang putih. Jurnal Hortikultura 17(4): 314-320 .

Karjadi, A.K. (2016). Kultur Jaringan dan Mikropropagasi Tanaman Kentang (Solanum tuberosum L). Balai Penelitian Tanaman Sayuran. Bandung.

Mahadi, I. W., Syafií., \& Agustiani, S. (2015). Kultur Jaringan Jeruk Kasturi (Citrus microcarpa) dengan menggunakan hormon kinetin dan Naftalen Acetyl Acid (NAA). Jurnal Dinamika Pertanian 3 (1): 37-44.

Mahadi, I. (2014). Induksi kalus kenerak (Goniothalamus umbrasus) berdasarkan jenis eksplan menggunakan metode in vitro. Agroteknologi Tropika 1(1): 18-22.

Nurwahyuni, I. (2013). Teknik in vitro jeruk keprok berastagi (Citrus nobilis 
brastepu) sebagai strategi biokonservasi mengatasi kepunahan jeruk lokal sumatera utara. Prosiding Semirata FMIPA Universitas Lampung 1(1): 420-427.

Parihar, N., \& Kumar S. (2015). in vitro seed germination dan clonal propagation through epicotyl explants of Aegle masrmelos. IJRSB 3(1): 6770 .

Rizal, S., Wisnu, E.M., \& Ellis, N. (2017). pengaruh pemberian beberapa konsentrasi kinetin terhadap induksi tunas aksilar tanaman kakao (Theobroma cacao 1.) secara in vitro. Jurnal Produksi Tanaman 5(1): 1512-1517

Shinta, D. (2017). Pengaruh BAPdan Kinetin Terhadap Pertumbuhan
Tunas Pisang Barangan (Musa paradisiacaL.) secara In Vitro [Skipsi]. Universitas Bengkulu.

Slamet, S. J., Pardal, M., Herman., \& Wartono. (2011). Regenerasi kedelai melalui kultur epikotil dan teknik aklimatisasi. Jurnal Penelitian Pertanian Tanaman Pangan 30(1): 38-42.

Widyastuti, K. (2017). Pengaruh Kombinasi NAA (Naphtalen Acetic Acid) dan BAP (Benzil Amino Purine) Terhadap Induksi Tunas Aksilar Tanaman Balsam (Polygala paniculata L.) secara In Vitro [Skripsi]. Universitas Islam Negeri Maulana Malik Ibrahim.

Zulkarnain. (2009). Kultur Jaringan Tumbuhan. Bumi Aksara. Jakarta. 